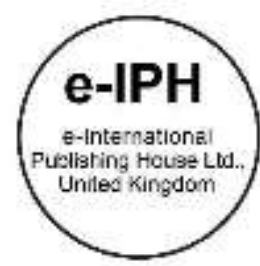

\title{
Does Festival-goer is a Risk-Taker?
}

\author{
Khairiah Ismail ${ }^{1}$, Nawal Hanim Abdullah ${ }^{1}$, Hamimah Hassan ${ }^{1}$, Norol Hamiza Zamzuri ${ }^{2}$ \\ 1 Universiti Putra Malaysia (UPM), Malaysia \\ ${ }^{2}$ Faculty of Business Management, Universiti Teknologi MARA Selangor, Puncak Alam Campus, 42300 Puncak Alam, Selangor \\ Malaysia
}

kyriazulaikha@gmail.com, nawal@upm.edu.my, ranalis@upm.edu.my,norol@uitm.edu.my

Tel of 1st Author: +6012-3813961

\begin{abstract}
This paper examines festivalgoers' risk-taking behaviour, focusing on a Malaysian music festival. A qualitative methodology based on in-depth interviews with 15 music festival-goers. The respondents' risk-taking behaviour was examined using DOSPERT, including financial, health and safety, recreation, ethical, and social domains. The findings show that the previous music festival's risks did not affect festivalgoers' motivation to attend. A significant impact on government, organiser, and society. Respondents offered some guidelines for organising a music festival. Since very few papers examine the prospect of risk in music festivals, the adoption of DOSPERT provides much-needed rich and credible data.

Keywords: Risk-taking Behavior, Risk, Music Festival, Event
\end{abstract}

eISSN: 2398-4287@ 2021. The Authors. Published for AMER ABRA CE-Bs by e-International Publishing House, Ltd., UK. This is an open access article under the CC BYNC-ND license (http://creativecommons.org/licenses/by-nc-nd/4.0). Peer-review under responsibility of AMER (Association of Malaysian Environment-Behaviour Researchers), ABRA (Association of Behavioural Researchers on Asians/Africans/Arabians) and cE-Bs (Centre for Environment-Behaviour Studies), Faculty of Architecture, Planning \& Surveying, Universiti Teknologi MARA, Malaysia.

DOI: https://doi.org/10.21834/ebpj.v6iSI4.2916

\subsection{Introduction}

Music festivals are considered unique events because they attract thousands of festivalgoers to the event for a variety of reasons (Bowen \& Daniel, 2005). The reason is that the festivalgoer is excited, rowdy, and sometimes intoxicated (Tangit, Kibat, \& Adanan, 2016). However, the presence of the music festival has changed society's perception of the outcome of the music festival. It is also reflected in their positive and negative observation throughout the organisation of the music festival. The sentence refers to several cases that have taken place during music festivals, such as illegal substances, sexual harassment, overcrowding, and fighting. However, the festivalgoers are still willing to take the risk of participating in the music festival, despite knowing these issues.

In the global context, the reasons why people attending music festivals are due to the opportunity to participate in social activities (Parker \& Ballantyne, 2011; Connell \& Gibson, 2004), to socialise, party, experience novelty, excitement and enjoy the festival programme (Bowen \& Daniels, 2005), create satisfaction (Crompton \& McKay, 1997), and to escape, social interaction and looking for excitement (Yoon \& Uysal, 2005). In the United Kingdom, 49.2\% of festivalgoers have claimed that music and artists are the main motivation behind their participation in the music festival (Gelder \& Robinson, 2009). Similarly, in Macau, the attendees were motivated to participate in the music festival by factors related to music (Vinnicombe \& Sou, 2017). Compared to China, people attended music festival is due to their spiritual escape, which has linked to their freedom (Li \& Wood, 2016).

In Malaysia, there is little literature on the motivation of the attendees to attend a music festival. Due to limited literature, a recent local study focused on visitors experiences while attending the Future Music Festival Asia in 2014, while 'choice of performances' indicated that they had been satisfied during the event (Tangit et al., 2016). Earlier, Shuib, Edman, and Yaakub (2013) found that most of the participants in the Rainforest World Music Festival were between the ages of 21 and 30. Moreover, Ismail and Meng (2017)

eISSN: 2398-4287@ 2021. The Authors. Published for AMER ABRA cE-Bs by e-International Publishing House, Ltd., UK. This is an open access article under the CC BYNC-ND license (http://creativecommons.org/licenses/by-nc-nd/4.0/). Peer-review under responsibility of AMER (Association of Malaysian Environment-Behaviour Researchers), ABRA (Association of Behavioural Researchers on Asians/Africans/Arabians) and cE-Bs (Centre for Environment-Behaviour Studies), Faculty of Architecture, Planning \& Surveying, Universiti Teknologi MARA, Malaysia.

DOI: https://doi.org/10.21834/ebpj.v6iSI4.2916 
showed that risk factors such as the disaster in crowds, safety failure, and poor safety failure caused music festivals to fail. However, this explanation illustrates the lack of reliable information about what makes festivalgoers eager to attend the music festival, even though they know that their action will result in positive or negative results. This paper, therefore, seeks to bridge this gap by investigating the risks between the festivalgoers and their risk-taking attitudes when participating in Malaysia's music festival.

This paper was divided into five parts. It begins with the first part of the literature review, which examines the risks in the music festival, the position of the music festival in Malaysia, and the risk-taking behaviour of festivalgoers. The second part will clarify the methodology used in this study, while the third part will highlight the findings on the risk behaviour of festivalgoers attending the music festival. Subsequently, part four of the discussion will discuss the relationship between research findings and literature. This paper will conclude with a recommendation for future research.

\subsection{Literature Review}

\subsection{Risk in Music Festival}

There is an increasing demand for the organisation of a music festival worldwide in the past few years. Despite this demand, there are several issues that have occurred during the event, such as theft, overcrowding, fighting, loss of life, drugs, accidents and injuries, severe weather, sexual assaults, riots, alcohol, food hygiene, health concerns and fire (Tangit, Kibat, \& Adanan, 2016). Águila (2010) added further with food poisoning, poor construction, social disorder, gangs, violence, carjacking, kidnapping, murder, air and water pollution, public nudity, celebrity appearance, natural disasters, bombs, and terrorism. These studies were then supported by Reid and Ritchie (2011), who also mentioned the seriousness of the risk identification as it could affect the outcome of activities of the event and the likelihood of loss.

In placing more emphasis, risk in a music festival is not a new issue at a global level. It's happened at a couple of music festivals. For example; terrorist attacks at BMP Electronic Music Festival Mexico (Stargardter, 2017), failure of the Fyre Festival in 2017 at The Bahamas (Vincent, 2017), murder at Bestival Music Festival (Fruen, 2017), the explosion at the German Music Festival (Chokshi, 2016), and a dust explosion at Color Play Asia Taiwan in 2015. These issues may arise when the organiser does not have a proper risk management plan that can be used to predict the risk, estimate the impacts, and identify the responsible personnel or crew for each risk. Indeed, a risk management plan can stand by the principle of 'the more you plan, the less will go wrong' (Ellert, Schafmeister, Wawrzinek, \& Gassner, 2015).

\subsection{Malaysia Music Festival}

In Malaysia, the position of the music festival is not actively supported by the government due to the drug overdose that occurred at the previous music festival. Indeed, some politicians declare music festivals as an immoral activity, especially when alcohol was served. Therefore, the government have cancelled many music festivals because they are concerned that such incidents can happen again and tarnish the image of Malaysia.

The festivalgoers, however, found this cancellation miserable. Because of only one case, the government prohibited most of the music festivals. In Malaysia, a demand is undeniably being made for a music festival. For example, in July 2019, the Arts, Live Festival and Event Association (ALIFE) petitioned the government to hear the voice of Malaysians who want more festivals and live concerts to be held in Malaysia. As of September 2019, the petition was signed by 16,465 people, and it shows how starving Malaysia festivalgoers are towards the organisation of music festivals. The question arises here is, what makes them want to participate in the music festival and tend to ignore the previous dangers?

\subsection{Risk-taking behaviour of festivalgoer's}

In the event context, risk-taking behaviour refers to protecting an individual from potential benefits or difficulties. The aforementioned possibility refers to any cases or incidents that may occur during an event. Undoubtedly, there are different types of risks that have occurred beyond the control or influence of the organiser. Interestingly, there has been a lack of consensus on how to measure risktaking as a disposition (Highhouse, Nye, Zhang, \& Rada, 2017) from either the attendees' or organiser's perspective. In this context, people can observe the disposition of risk-taking behaviour through their physical activity, such as attending a music festival. It is because a music festival is a social assembly platform where people of different ages and gender assemble to enjoy music, environment, and performance.

The Domain-Specific Risk-Taking (DOSPERT) behaviour theory will be used in the study to guide the research process. This theory was developed by Weber, Blais, and Betz in 2002 and has been widely used to determine risk attitudes (Butler et al., 2012). There are five risk domains assessed in this theory, such as financial, health and safety, recreational, ethical and social. In general, DOPSERT was used by previous researchers to determine the propensity of risk-taking behaviour among people from a different perspective. However, this theory has not yet been studied by festivalgoers. The following table shows an example of authors who, in their preceding study, used DOSPERT.

Table 1. A list of DOSPERT studies

\begin{tabular}{lcc}
\hline Authors Study focus & Respondents \\
\hline
\end{tabular}




\begin{tabular}{llll}
\hline Farnham et al. (2018) & $\begin{array}{l}\text { Individual risk attitudes and health } \\
\text { behaviours during travel }\end{array}$ & Travellers & Quantitative: 75 survey \\
\hline Lozano et al. (2017) & Spanish validation of DOSPERT & Volunteer & Quantitative: 826 survey \\
\hline Highhouse et al. (2016) & Evidence of general risk-taking & Workers & Quantitative: 921 survey \\
\hline Wu and Cheung (2014) & Factor analysis of risk-taking attitude & Chinese undergraduate students & Quantitative: 205 survey \\
\hline Khodarahimi (2015) & $\begin{array}{l}\text { Relationship between sensation- } \\
\text { seeking and risk-taking behaviour }\end{array}$ & Young lranian adults & Quantitative: 300 questionnaires \\
\hline Rolison et al. (2013) & Risk-taking and age & Younger age range and older adults & Quantitative: 528 survey \\
\hline Butler et al. (2012) & Medical risk attitude & Patients & Qualitative and Quantitative: 8 \\
& & & cognitive interviews, 100 online \\
& & surveys, and 30 telephone survey \\
\hline Blais and Weber (2006) & Relationship between apparent risk- & Adult population & Quantitative: 359 online survey \\
\hline
\end{tabular}

\subsection{Methodology}

The aim of this study is to explore respondent narrative views on risk-taking behaviour in attending a music festival. The best methodology to be used is, therefore, qualitative research. This method is chosen because authors believe that it will provide a deeper understanding of the behaviour of the respondents and provide a broader overview of the research subject (Silverman, 2016). The results of this study are obtained primarily from primary and secondary data. In order to detect relevant literature, authors begin with a collection of secondary data from various journal papers, online sources, and textbooks. These secondary data, as suggested by Merriam (2002), are useful for the verification of findings on the basis of other data.

Moreover, the process of collecting primary data has proceeded with fieldwork, whereas it is mainly generated from face-to-face semi-structured interviews with 15 respondents, as suggested by Bertaux (1981) in the Guest, Bunce, and Johnson (2006) surveys, with 15 respondents, is considered to be an acceptable number of sample sizes for qualitative research. Based on their background, this respondent has chosen to actively participate in any music festival, either locally or internationally, every year. As a result, patterns of risk-taking behaviour varied among demographic groups. The selection of respondents was based on purposive sampling, which relied on their status as festivalgoers.

This is because of their different nationality, ages, and races. The majority of respondents in this study are Malaysian, followed by Maldivian, Indonesian, and American. In order to observe a variety of risk-taking behaviours, the age of the respondent varied from 19 to 40 years, with most of them male. Eight of the respondents are students, with the remainder working in different industries. The researchers spent between 40 minutes and 1 hour in a semi-structured interview, while two sessions of focus group discussion and nine sessions of the one-to-one interview were included. All interviews were facilitated either in the respondent office or in the university area. Respondents have approached the application via email and WhatsApp, and a copy of the letter of consent has been attached. Permission for audio recording has been granted to respondents prior to the start of the interview. Once the interviews had been transcribed, the data were coded and sorted using Atlas.ti to identify themes. According to Friese (2019), Atlas.ti will help researchers automatically create a data group and theme.

\subsection{Discussion of Findings}

As mentioned in the literature review, the Domain-Specific Risk-Taking (DOSPERT) theory has been used as a guide to exploring risktaking behaviour among festivalgoers. Hence, the theme of this study has been identified earlier as the domain of financial, health and safety, recreational, ethical and social. Atlas-ti will then help authors reveal the risk-taking behaviour of the festivalgoer in the theory of DOSPERT.

\subsection{Financial}

According to Leenders et al. (2005), the music festival had different tickets at different prices. The higher the budget, the higher the ticket price, and the better the performers will perform at the music festival. More emphasis may be placed on the issue of financial risks to the level of risk-taking among festivalgoers. For example, some festivalgoers might face the unaffordable issue of ticket prices. The FMFA 2014 (RM428), RWMF 2019 (RM600) and Good Vibes 2019 (RM450) show that the price for a ticket to a festival is not cheap by taking a few examples of all-day access for a handful of music festivals organised in Malaysia. Respondents raised it by saying:

"The price of the ticket is quite expensive. Similar to a concert, and so on. So, it depends a lot on the theme of the music festival.."

"The most expensive and huge amount of money l've spent is probably in Australia. The ticket alone cost me about RM700 for a one-day event. It's just a ticket, not including any other expenses, flight tickets, etc... So, it was about 3 to 4 thousand, including expenses, and all that..." 
"The event industry is not very stable... You know, sometimes I bare and took the risk of the money I spent on this event."

(Respondent 3)

This point shows that the respondents are aware that the ticket to the music festival has been recognised as expensive. This indicator was also found in the Nordvall and Heldt (2017) study, which one of their respondents said 'ticket is too expensive.' Jackson, Henderson, and Musgrave (2014) supported this sentence because they said it was travelling. But from an organisers point of view, the festival is very costly and hard to produce (Booth, 2016).

\subsection{Health and safety}

The result has shown that festivalgoers are aware of the safety of the music festival. They understand that there are risks and hazards during an event, but they are not influenced by attending a music festival. Surprisingly, some of the respondents take the risk of doing something unlawful. This respondent replied:

"There are people who are going to do it (bribe) ... Just to get in ... Just bribe the guard, man... I did it before. Hahaha... At that time, I was 16.. I've been to a music event ... I'm giving RM50. There are a lot of people, but only a few security guards. I just said, bang bolehlah (let me go, brother). And he's allowed me to.

(Respondent 2)

Apart from that, some of the respondents shared their experiences as witnesses of a few cases, such as people who bring drugs, alcohol, and sex to music festivals. Undoubtedly, they tend to ignore these people because their motive is simply to enjoy music. These views were shared by the respondents below:

"Participating with sex... I saw... But this is really rare... Well, because you know... the crowd... hot...dirty. Maybe three out of 20 are going to do it. We didn't find a girl here. We want to enjoy.."

(Respondent 13)

"My experiences are, when I go to the Malaysia music festival, I expect to see a lot of people who are on drugs, because that's something here.. I've always said it was a constant. But when I go overseas, there's a lot of people who... yes, they're taking drugs, but there are far more people who don't use drugs.

(Respondent 1)

"It's like a norm for the participants to drink. Mostly by norm .."

(Respondent 4)

"There is a risk when it comes to organising a music festival. Especially when people are trying to sneak in and out. For example, if the venue can hold 800 seats. Suddenly there were 1,400 attendees on the day of the event. Why? Why? Because people are sneaking in lah."

(Respondent 8)

\subsection{Recreational}

The findings showed that there was no issue in attending a music festival alone among festivalgoers. In their study, Ballantyne et al. (2014) found that attendees over 30 years of age are more likely to attend a music festival on their own than those below the 30 s. However, that sentence was upheld by the respondent who said:

"I have already done that. Be there alone since I was 19 years old. It's a good way to find a friend or to mingle around. I can travel by myself. No problem with that."

(Respondent 2)

\subsection{Ethical}

Ethical decision may reflect from the situation between attendees and the organiser (Glover, Bumpus, Sharp, \& Munchus, 2002). This sentence relates to the finding whereas the respondents said:

"Hmmm, okay. The drinking age in Malaysia is 21 years old. But, what if the bouncer doesn't see you like 21.. Although if you're 21, but you'realready 31..Also, sometimes show IC doesn't work.. This is a very easy example lah you know.. If you're caught, give something to the authority (bribe), then you can pass.."

(Respondent 4)

"It's happening (refers to the issue of bribery). Bribe, bawah meja (under the table).."

(Respondent 2)

Shockingly, the respondent disclosed that a bribery issue had occurred during a music festival. That's why some of the festivalgoers are willing to take unethical action because they assume that bribery can help if they get caught by the authorities.

\subsection{Social}

The finding revealed that festivalgoers are willing to attend a music festival because it brings a unique experience which also creates an emotional response (Emma \& Moos, 2015). It has been clarified by the respondent who said: 
"Music festivals create unique experiences that are incredibly memorable.."

(Respondent 7)

However, there is a respondent who argues that they have been influenced by international music and artists by the culture of the western country. Since there is a limited number of music festivals organised in Malaysia, they are willing to attend any music festival approved by the authority.

"Because there's demand..especially as young people aaa.. they want all of these acts to come to Malaysia.. to experience all of that.. we are exposed to the western country. so, we want our international DJ to come along.. we want to see them alive."

(Respondent 3)

\subsection{Discussion}

The above evidence shows that festivalgoers have a diverse motivation, which explains their risk-taking behavior when they attend a music festival. The findings showed that the narrative point of view among festivalgoers does relate to the DOSPERT domain. Interestingly, the findings also revealed, from a negative perspective, what happened during the organisation of the music festival. On this line, the authors discovered bribery, drugs, crowds, alcohol, and sex that had taken place during the music festival. In fact, these views are consistent with the literature.

The above results also suggest a few rules for organising music festivals that should be considered by the organiser. This includes effective policing crowd (Hoggett \& Stott, 2010), training of security personnel (Harris, Jenkins \& Glaser 2006), risk management rules (Dionne, 2013), and safety measurement (Havere et al. 2011). On the other hand, the results showed that festivalgoers take a risk approach at the music festival in Malaysia. Sadly, the number of previous studies focusing on event risk in Malaysia is insufficient.

\subsection{Conclusion}

In conclusion, festivalgoers take risks from the fields of financial, health and safety, recreation, ethical and social issues. But the motivation for participating in the music festival does not reflect it. This means that festivalgoers are willing to take the risk of attending a music festival despite knowing all the risks and issues that have arisen from the previous music festival. Usually, their main motivation is to enjoy music. In another perspective, it was suggested that the implementation of the risk management plan is vital for all event organisers. Further research could be conducted in the future on the perspective of the organisers, which focuses their risk-taking behaviour on the organisation of music festivals in Malaysia. As previously stated, the government has rejected some music

\section{References}

Blais, A. R., \& Weber, E. U. (2006). A domain-specific risk-taking (DOSPERT) scale for adult populations. Judgment and Decision making, 1(1).

Booth, A. (2016). Negotiating diasporic culture: festival collaborations and production networks. International Journal of Event and Festival Management, 7(2), $100-116$.

Bowen, H. E., \& Daniels, M. J. (2005). Does the music matter? Motivations for attending a music festival. Event Management, 9(3), 155-164.

Crompton, J. L., \& McKay, S. L. (1997). Motives of visitors attending festival events. Annals of tourism research, 24(2), 425-439.

Dionne, G. (2013). Risk management: History, definition, and critique. Risk Management and Insurance Review, 16(2), $147-166$.

Ellert, G., Schafmeister, G., Wawrzinek, D., \& Gassner, H. (2015). "Expect the unexpected" New perspectives on uncertainty management and value logics in event management. International Journal of Event and Festival Management, 6(1), 54-72.

Friese, S. (2019). Qualitative data analysis with ATLAS. ti. SAGE Publications Limited.

Gelder, G., \& Robinson, P. (2009). A critical comparative study of visitor motivations for attending music festivals: A case study of Glastonbury and V Festival. Event Management, 13(3), 181-196.Getz, D. (2008). Event tourism: Definition, evolution, and research. Tourism Management, 29(3), 403-428.

Harris, C. R., Jenkins, M., \& Glaser, D. (2006). Gender differences in risk assessment: why do women take fewer risks than men?. Judgment and Decision making, 1(1), 48.

Highhouse, S., Nye, C. D., Zhang, D. C., \& Rada, T. B. (2017). Structure of the Dospert: Is There Evidence for a General Risk Factor? Journal of Behavioral Decision Making. https://doi.org/10.1002/bdm.1953

Hoggett, J., \& Stott, C. (2010). The role of crowd theory in determining the use of force in public order policing. Policing \& Society, 20(2), 223-236.

Ismail, K., \& Meng, N. K. (2017). Measuring The Failure Factors of Festival: A Case of FMFA. Organised and Hosted by, 214.

Jackson, C., Henderson, S., \& Musgrave, J. (2014). Changing audience behaviour: festivalgoers and throwaway tents. International Journal of Event and Festival Management. 
Leenders, M. A., van Telgen, J., Gemser, G., \& Van der Wurff, R. (2005). Success in the Dutch music festival market: the role of format and content. International Journal on Media Management, 7(3-4), 148-157.

Li, Y. N., \& Wood, E. H. (2016). Music festival motivation in China: Free the mind. Leisure Studies, 35(3), 332-351.

Merriam, S. B. (2002). Introduction to qualitative research. Qualitative research in practice: Examples for discussion and analysis, 1(1), 1-17.

Nordvall, A., \& Heldt, T. (2017). Understanding hallmark event failure: A case study of a Swedish music festival. International Journal of Event and Festival Management, $8(2), 172-185$.

Packer, J., \& Ballantyne, J. (2011). The impact of music festival attendance on young people's psychological and social well-being

Shuib, A., Edman, S., \& Yaakub, F. (2013). Direct expenditure effects of the rainforest world music festival 2009 in Santubong, Sarawak. International Journal of Business \& Society, 14(2).

Silverman, D. (Ed.). (2016). Qualitative research. Sage.

Stargardter, G. (2017). At least 5 dead, 15 hurt in shooting at Mexico's BPM music festival. Retrieved from: https://www.reuters.com/article/us-mexico-violence-bpm/atleast-5-dead-15-hurt-in-shooting-at-mexicos-bpm-music-festival-idUSKBN1501LE

Tangit, T. M., Kibat, S. A., \&Adanan, A. (2016). Lessons in Managing Visitors Experience: The Case of Future Music Festival Asia (FMFA) 2014 in Malaysia. Procedia Economics and Finance, 37, 52-57.

Vincent, A. (2017). Fyre Festival: How the disaster unfolded and why Bahamas officials have the site on lockdown. Retrieved from: https://www.telegraph.co.uk/music/news/fyre-festival-disaster-unfolded-bahamas-officials-have-site/

Vinnicombe, T., \& Sou, P. U. J. (2017). Socialisation or genre appreciation: the motives of music festival participants. International Journal of Event and Festival Management, 8(3), 274-291. 